Article

\title{
The Relationship between Team Hometown Diversity and Team Creativity: From the Chinese Perspective
}

\author{
Jingli Li *(D, Min Zhao, Guanjun Xia and Chao Liu \\ Business School, Hohai University, Nanjing 211100, China; zhaomin@hhu.edu.cn (M.Z.); \\ xiaguanjun@hhu.edu.cn (G.X.); liu-chao@hhu.edu.cn (C.L.) \\ * Correspondence: lijingli@hhu.edu.cn; Tel.: +86-158-5185-5369
}

Received: 26 July 2018; Accepted: 26 September 2018; Published: 28 September 2018

\begin{abstract}
Since no specialized work has researched the relationship between team members' hometown diversity (team hometown diversity) and team creativity, we investigated their underlying relationship by conducting a two-wave survey from 304 employees in 54 teams and 54 team leaders from 17 companies. The results proved that team hometown diversity was negatively related to both team information exchange and team creativity, while team information exchange was significantly positively associated with team creativity and the mediation effect of team information exchange between team hometown diversity and team creativity was verified. The moderation role of team identification in the relationship between team hometown diversity and team information exchange as well as the moderation function of team conformity on the relationship between team information exchange and team creativity were both verified. This work made at least four contributions. Firstly, it was among the first to research the impact of team hometown diversity on team creativity, which supplemented the gap and provided a new perspective for exploration of team creativity in future. Secondly, we adopted a two-wave design to check the dynamic impact of earlier team information exchange and team conformity on team creativity afterwards, which can be replicated for future studies. Thirdly, by using supervisor and subordinate ratings together and conducting electronic and paper surveys together, the results were more persuasive. Finally, we included a large dataset from a broad range of companies, which maximized the variables and generated our results. The implications and limitations were also illustrated.
\end{abstract}

Keywords: team hometown diversity; team identification; team information exchange; team conformity; team creativity

\section{Introduction}

Team creativity is vital to organizational success [1] and sustainable development [2]. Researching the impact of demographic diversity on team creativity has recently attracted more attention [3-5], however, their relationships were still complex or unclear [6-9].

Specifically, in line with the perspective of diversity values [10], demographic diversity has been viewed as an important contributing factor to team creativity since diverse team members are exposed to different backgrounds and experiences [11-13], which can promote their flexible thinking and formation of creative ideas [14-16]. However, according to the similarity-attraction paradigm [17], homogeneous teams are more productive than heterogeneous ones because the members of homogeneous teams are more likely to trust each other on the basis of similar attributes, which enhances team interaction and cooperation. In addition, some scholars have proven that demographic diversity, such as age, gender, and ethnicity, impacts on team creativity in a negative way $[5,18]$ as demographic diversity promotes subgroup categorization on the basis of similar attributes and can be detrimental for the interaction of new ideas and the generation of creative solutions $[19,20]$. 
Specifically, people would like to treat ones with the same demographic attribute as one group and tend not to trust the others and the divergent thoughts of team members will not be easily exchanged, which could make communication difficult and cause conflict and mistrust [21,22], decreasing the potential for creative solutions [4].

As stated above, demographic diversity seems to influence team creativity in a more fundamental and pervasive way since demographic features are easy to distinguish. Social psychology research has found that people categorize others based on the first impression formed by easily observable features such as gender, sex, and race [23-25] and these features are consistent for the categorization process $[25,26]$. Demographic attributes were found to be related to team members' perceptions of similarity to different extents and race was found to be the most predictable [27]. Race referred to any group of people sharing the same ancestry, family, clan, or lineage [28] (p. 549). Since this work was conducted in mainland China, most of the respondents belonged to the same race, however, they were from different home provinces and would likely to categorize themselves into different subgroups.

The influence of team hometown diversity can be best explained by social identity theory. According to the theory, people derive their identity largely from the social categories to which they belong [29]. In addition to categorizing themselves, people categorize others on the basis of observed or known social or personal attributes such as hometown. People from the same hometown are likely to categorize themselves into the same group, which promotes communication, interaction, and friendship formation even with strangers when they are demographically similar.

However, by reviewing the literature about demographic diversity and team creativity, there exists no research on team hometown diversity and team creativity, while the meaning of hometown implies a lot for employees, especially in China. This represents a special expression of cultural diversity, which implies a combination of ethnic, linguistic, and religious diversity. Team hometown diversity is a specific type of demographic diversity, which is an important factor influencing team outcomes in both Western and Chinese contexts.

According to Confucianism, an individual is fundamentally a social or relational being [30]. People from the same hometown will view themselves as familiar persons. For example, when two modern Chinese people meet for the first time, they inquire about each other's hometown and are attracted to each other when they have the same hometown. This phenomenon can be best explained by social exchange theory [31]. Interpersonal favors and generosity are rendered with the anticipation that they will be reciprocated [32].

As previously stated, demographic diversity may promote team creativity since different knowledge and experiences collide [33,34], while it may also prohibit team creativity due to social categorization $[21,22]$. The inconsistency in the literature has been attributed to the possible boundary constraint of this relationship [8]. Past research had used moderators such as knowledge disparity [5] and perspective taking [35], and mediators such as social capital [5], and information elaboration [35]. Additionally, the expectations model [36], which is based on social categorization theory, suggests an indirect link between demographic diversity and team performance through interactions consistent with their expectations. Thus, team information exchange may act as the mediator between team hometown diversity and team creativity.

However, what if team members share common attributes other than hometown? What if members highly identify their team despite having a diverse hometown? These thoughts have enlightened us on the moderator of team identification. Similarly, the relationship between team information exchange and team creativity may be moderated by team conformity as suggested in the previous work [3].

In this paper, we aimed to explain how team hometown diversity influences team creativity through team information exchange and the moderating function of team identification on the relationship between team hometown diversity and team information exchange as well as the moderating function of team conformity on the relationship between team information exchange and team creativity. 
This work made at least four contributions. First, this research was among the first to research the impact of team hometown diversity on team creativity, which supplemented the gap and provided a new perspective for exploration of team creativity in future research. Second, we adopted a two-wave approach to check the dynamic impact of earlier team information exchange and team conformity on team creativity afterwards. Third, by using supervisor and subordinate ratings together and conducting electronic and paper surveys together, the results were more persuasive. Fourth, we included a large dataset from a broad range of companies, which maximized the variables and generated our results.

\section{Theory and Hypothesis}

\subsection{Team Hometown Diversity and Team Information Exchange}

Team hometown diversity refers to what extent the employees in one team come from different hometowns. Team information exchange refers to the interaction of knowledge and information in the team. The effects of demographic diversity can be best explained by the social categorization and social identification processes $[37,38]$. Demographic variances are usually visible and easy to tell, which may influence one's first impression of others in a team or group [24], and people from the same hometown feel much closer when they meet for the first time [39]. People naturally categorize themselves into different sub-groups and form their own values and beliefs naturally [28]. Demographics are also important for the self-identity of individuals, which can be illustrated by the statement "An individual's personal identity is highly differentiated and based in part on membership in significant social categories, along with the value and emotional significance attached to the membership" [40] (p. 184).

According to social psychological research, people like to share resources with others who are similar to themselves. People from the same place usually show similarities such as dialect, food preference, and even values. These shared codes and language imply that a common set of terms, symbols, and understandings allow individuals to exchange information effectively with one another [41,42] and promote members in one team to be more motivated and collaborative. In contrast, differences in these attributes reduce the possibility of interactions between individuals.

Thus, we hypothesize that:

Hypothesis 1 (H1). Team hometown diversity is negatively related to team information exchange.

\subsection{Moderation Effect of Team Identification}

Team identification means the extent to which individuals define themselves in terms of their organization and its representative attributes [43], has derived primarily from social identity theory [29]. According to the theory [29], when team identification is high, team members are likely to trust each other and share information [5]. This is consistent with the social exchange theory [44], which suggests that trust is the precondition for social exchange [45]. Additionally, when employees identify the team to a large extent, they will have a solid motivation to perform well [46], thus stimulating the information integration with teammates [47].

On the other hand, when team members identify their team, they are likely to identify the team culture and team goal. From this perspective, they can exchange their experiences and information effectively since they clearly know team goals [48]. In this paper, we argue that team hometown diversity would be negatively related to team information exchange in $\mathrm{H} 1$. Accordingly, we propose that the negative relationship can vary under different circumstances. When team identification is high, team hometown diversity impacts on team information exchange in a less negative way than when team identification is low. By realizing that they shared the same identifications for the company [49], employees tend to view the divergence of demographic diversity as less important than the same identity [50] and are more willing to enhance team information exchange [42]. In contrast, when team 
identification is low, effective communication would take place in smaller communities where they own similar attributes, such as language or code. Thus, we hypothesize that:

Hypothesis 2 (H2). The relationship between team hometown diversity and team information exchange is less negative when team identification is higher than it is low.

\subsection{Team hometown Diversity and Team Creativity}

The similarity-attraction paradigm [17] suggests that members of a homogeneous team trust each other because of similar attributes, and they would like to share their knowledge to find new solutions. Trust and communication are undermined in the different subgroups [20,38], thus divergent thoughts will not be exchanged and used, and the creative potential will decrease.

Research suggested that nationality diversity could harm team creativity since nationality was often used as the basis for the categorization process [51,52] by dividing teams into subgroups. Demographic diversity could cause uncomfortable feelings and less integration for team members and a higher possibility of turnover [53], and visible dissimilarity was also found to be negatively related to team involvement in the long run [54]. On the contrary, demographic similarity usually promoted members in one team to be more motivated and collaborative. As the structural hole theory implies that connections to others who are not themselves connected foster good ideas [55], closure in individual networks is positively related to the innovation involvement [56]. However, in a hometown diverse team, these connections are less and team creativity would be damaged. Thus, we hypothesize that:

Hypothesis 3 (H3). Team hometown diversity is negatively related to team creativity.

\subsection{Team Information Exchange and Team Creativity}

Team information exchange means "an ongoing process of reflection and action, characterized by asking questions, seeking feedback, experimenting, reflecting on results, and discussing errors or unexpected outcomes of actions" [57] (p. 353). Team creativity refers to "the joint novelty and usefulness of ideas regarding products, processes, and services" [35] (p. 983).

The componential model of creativity posits that informational resources are important links and the preparatory stage to individual creativity [58]. Similarly, according to the absorptive capacity theory [59], it is essential for employees to understand and integrate new knowledge to generate novel ideas, which can be acquired from knowledge exchange. Exchanging information among employees will promote the interaction of cognitive resources, acquisition and creation of novel solutions $[14,60,61]$, which enhances team creativity [58,62]. Team information exchange has been proven to be positively related to team creativity performance [63]. Thus, we hypothesize that:

Hypothesis 4 (H4). Team information exchange is positively related to the team creativity.

\subsection{Mediation Effect of Team Information Exchange}

The relationship between demographic diversity and team performance has presented mixed results [9]. Consequently, researchers have begun to explore the functions of mediators between this relationship [38]. Team information exchange and processing have been assumed to be a key link from team diversity to team creativity. People from the same hometown are more likely to trust each other and be willing to exchange their ideas, which enables diverse information and knowledge to supplement each other to generate novel ideas. Thus, we hypothesize that:

Hypothesis 5 (H5). Team Information exchange mediates the relationship between team hometown diversity and team creativity. 


\subsection{Moderation Effect of Team Conformity}

Values are fundamental for shaping people's goals and behaviors [64]. Values are defined as desirable trans-situational goals that serve as guiding principles in the life of a person. They can motivate action-giving it directly and they function as standards for judging and justifying action ([65], p. 21). Team information exchange was hypothesized positively related to team creativity before, meanwhile, team values might moderate this relationship. Among the values Schwartz defined [66], conservation had been tested to function as a moderator of the relationship between transformational leadership and individual creativity [64]. Conformity, as one dimension of conservation, appears to be related with creativity more directly than the other two dimensions of tradition and security since creative people are usually not conformist [67]. However, the relationship between conformity and creativity had not been further researched at the team level in their work. Since the importance of team values $[68,69]$, we eager to know how team conformity (short for team members' value of conformity) influences team creativity.

Conformity refers to the restraint of actions, inclination, and impulses likely to upset and harm others or violate social expectations and norms [66] (p. 705). Conformity is the value of guiding attitudes and behaviors in situations [3] and may influence the information exchange and creativity. The definition of conformity implies adherence to norms, unwillingness to be different [70], and reluctance to engage in creative behavior [71], which suggests that the relationship between team information exchange and team creativity varies when team conformity varies: when team conformity is high, team members are not inclined to object to the others' different views and adopt new ideas since they are not willing to offense others, which is detrimental for the team creativity. In other words, team conformity may contribute to replication of established procedures but not be a beneficial practice for creativity [71,72].

Thus, we hypothesize that:

Hypothesis 6 (H6). Team information exchange is more positive with team creativity when team conformity is low, rather than when it is high.

All hypotheses are shown in Figure 1.

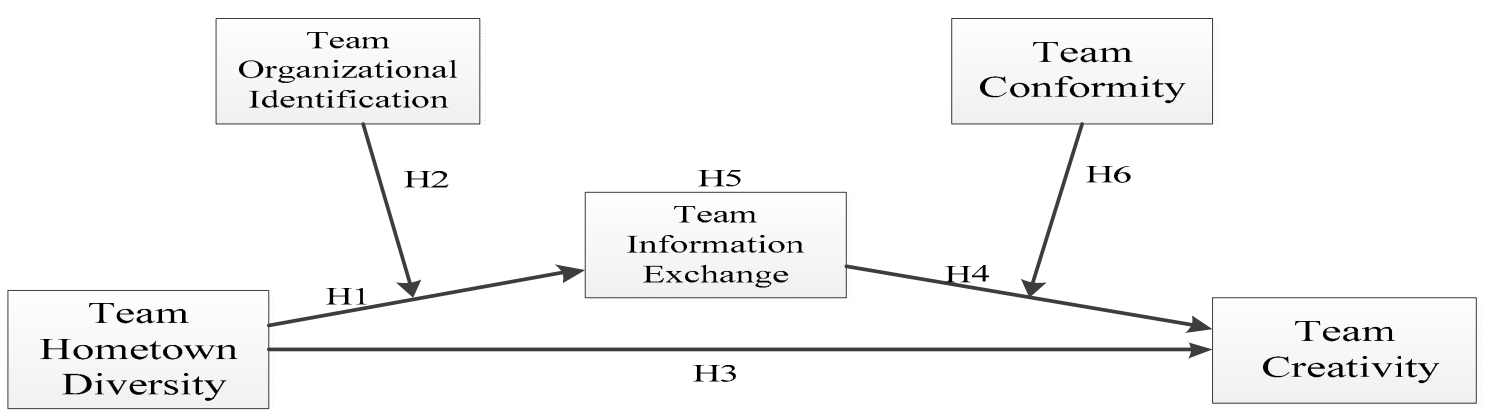

Figure 1. Hypothesized model.

\section{Methods}

\subsection{Participants and Procedure}

As the original questionnaires were written in English, they were translated into Chinese by a faculty member in the English department, who was a native Chinese speaker and had studied English for more than 30 years. The back-translated version was reviewed by students in the business school whose native language was English, while the Chinese version was evaluated by the business school students who were native Chinese speakers. Both groups confirmed the equivalency between the two versions, which was consistent with the back-translation procedure [73]. Two members of our research team explained the purpose of the survey and the procedures to each respondent. 
The researchers assured the potential study participants that their responses would only be used for academic research and would be kept confidential. As this work was a two-wave study, we collected data at two different times. At Time 1, we asked the team members to complete survey of their demographic features and scales of information exchange, organizational identification, and conformity. Two months later, the direct team leaders of the employees who answered the survey in Time 1 were asked to rate the creativity of their teams. All respondents randomly received either the website linked or paper questionnaires, thus avoiding common methods variance [74], and those who took part in the survey would have chances to enter a draw.

Considering that there was the possibility of an incomplete group when team members were absent or had resigned, we contacted with a certain leader at each company and asked them to collect all of the data for the whole group. It took us four months to finally collect all of the data. During the process, we measured 412 employees from 80 teams in 25 companies covering both state-owned and private companies. We received 345 ( $83.74 \%$ answer rate) responses from 68 teams in 20 companies. Since our research was at the team level and all of the team members should be included, we deleted the incomplete and invalid responses and finally obtained a dataset of 303 employees from 54 teams in 17 companies. There were $170(56.11 \%)$ males and $133(43.89 \%)$ females. A total of $132(43.56 \%)$ employees' ages ranged from 19 to $28 ; 122(40.26 \%)$ employees were aged between 29 to $38 ; 39$ (12.87\%) employees were aged from 49 to 58 , and the remaining 10 (3.31\%) employees were older than 59. Regarding tenure, 54 of 303 (17.82\%) employees had worked for less than 2 years; $136(44.88 \%)$ employees had worked for more than 2 years but less than 5 years; 77 (25.41\%) employees had worked for more than 5 years but less than 11 years; 34 (11.22\%) employees' working experience ranged from 11 to 20 years; and two $(0.66 \%)$ had worked for more than 20 years. There were three $(17.65 \%)$ state-owned companies and $14(82.35 \%)$ private companies in our dataset, and $2(11.76 \%)$ of the 17 were listed companies. The company sizes ranged from 10 to 150 and the average company size was 101 . Team size ranged from 2 to 15 and the average team size was 5.63 .

\subsection{Measurements}

\subsubsection{Team Hometown Diversity}

We asked the respondents to list their hometowns in the survey. We calculated the diversity by using the formula of Blau's index of heterogeneity [75], $1-\sum\left(\mathrm{P}_{\mathrm{i}}\right)^{2}$, where $\mathrm{P}_{\mathrm{i}}$ is the portion of a team member in the $i$ th category.

\subsubsection{Team Information Exchange}

We used the four-item scale from Gong et al. [58], which was adopted from Subramaniam and Youndt [76]. A sample item was, "I am skilled at collaborating with each other in my unit to diagnose and solve problems" ( $1=$ strongly disagree to $5=$ strongly agree). Since we measured the team information exchange in the research model, we aggregated the scores of individual information exchange to obtain a score of team information exchange according to the previous research [77]. High level of agreements between the reported degree of information exchange of team members (mean $\left.r_{w g}=0.95\right)$ and aggregate reliability (Cronbach's $\left.\alpha=0.88\right)$ and reliability $(\operatorname{ICC}(1)=0.64, \operatorname{ICC}(2)=0.88)$ justified averaging the individual responses to the team level.

\subsubsection{Team Identification}

We used the six-item scale from Mael and Ashforth [43], which has also been used in other work [71,78]. A sample item was, "When someone praises (name of company), it feels like a personal compliment" ( 1 = strongly disagree to $5=$ strongly agree). Since we measured the team identification in this work, we aggregated the scores of individual information exchange items to obtain a score for team information exchange according to the previous research [77]. (mean $r_{w g}=0.97$, Cronbach's $\alpha=0.89, \operatorname{ICC}(1)=0.57, \operatorname{ICC}(2)=0.89)$. 


\subsubsection{Team Creativity}

We used the four-item scale [27], which was originally generated from Amabile [79] and has also been used in other work [80], which measured the newness, usefulness, and significance of the team. We averaged the scores of items and obtained a score of team creativity (Cronbach's $\alpha=0.88$ ).

\subsubsection{Team Conformity}

The conformity scale included four items and was created by Kirton [67] and has been used in other works $[71,81]$. One item was "I try not to oppose team members" ( $1=$ strongly disagree to $5=$ strongly agree). Since team conformity is a kind of team values, we followed the solution of previous work [68] and aggregated the scores of individual conformity to obtain a score for team conformity (mean $r_{w g}=0.96$, Cronbach's $\alpha=0.81$, ICC $(1)=0.51, \operatorname{ICC}(2)=0.81$ ).

\subsubsection{Control Variables}

Based on past researches, team size [6], team gender diversity [82], team age diversity [83], team tenure diversity [68] were chosen as the control variable. To calculate the diversity of team gender, team age, and team tenure, we used the formula of Blau's index of heterogeneity [75], $1-\sum\left(\mathrm{P}_{\mathrm{i}}\right)^{2}$, where $P_{i}$ is the portion of a team member in the $i$ th category. We used the number of employees in the team as team size. We also tried to set company size and company ownership type as control variables at the organizational level, however, the variances explained by them could be neglected, which suggested the multi-level analysis was not suitable for this work.

\subsection{Mediation and Moderation}

To check the function of mediation and moderation, we conducted regression analyses. To test the moderation effects of team identification and team conformity, we centered on team hometown diversity, team identification, team information exchange, and team conformity to minimize the effects of any multi-collinearity among the variables [76].

\subsection{Validity}

We conducted a confirmatory factor analysis (CFA) for team identification, team information exchange, team conformity, and team creativity and all of the questionnaire items were loaded significantly onto their constructs $(p<0.01)$ by using Amos 21 [84]. Since team hometown diversity was measured only by a single item, it was excluded from the confirmatory factor analysis based on the previous research [8], and the model including the four factors fitted the data better than the others $\left(\chi^{2} / d f=233.47 / 129=1.81\right.$, TLI $=0.94, \mathrm{CFI}=0.96$, RMSEA $\left.=0.05\right)$. Thus, the discriminant and convergent validities of the constructs were acceptable.

\section{Results}

\subsection{Preliminary Analysis}

All of the correlations are shown in Table 1. From Table 1, team hometown diversity, team information exchange, team identification, and team creativity were significantly correlated, which demonstrated the necessity of the regression. 
Table 1. Means, standard deviation, and correlations.

\begin{tabular}{|c|c|c|c|c|c|c|c|c|c|c|c|}
\hline Variable & $\mathbf{M}$ & SD & 1 & 2 & 3 & 4 & 5 & 6 & 7 & 8 & 9 \\
\hline 1.GD & 0.32 & 0.19 & - & & & & & & & & \\
\hline 2.AD & 0.46 & 0.19 & 0.225 & - & & & & & & & \\
\hline 3.TD & 0.47 & 0.20 & 0.164 & $\begin{array}{c}0.399 \\
* *\end{array}$ & - & & & & & & \\
\hline 4.TS & 5.63 & 2.89 & $\begin{array}{c}0.328 \\
*\end{array}$ & 0.246 & $\begin{array}{c}0.331 \\
*\end{array}$ & - & & & & & \\
\hline 5.HD & 0.69 & 0.19 & 0.164 & 0.026 & 0.033 & $\underset{* *}{0.514}$ & - & & & & \\
\hline 6.IE & 3.41 & 0.54 & -0.168 & 0.05 & 0.006 & $-\underset{* *}{-0.514}$ & $\underset{* *}{-0.783}$ & - & & & \\
\hline 7.TI & 2.64 & 0.69 & -0.244 & -0.196 & -0.048 & $-\underset{* *}{-0.608}$ & $\underset{* *}{-0.710}$ & $\underset{* *}{0.779}$ & - & & \\
\hline 8.CO & 2.51 & 0.42 & 0.076 & -0.233 & 0.212 & 0.058 & -0.055 & 0.046 & 0.013 & - & \\
\hline 9.CR & 3.63 & 0.65 & -0.149 & 0.016 & 0.034 & -0.487 & $-\underset{* *}{0.798}$ & $\begin{array}{c}0.862 \\
* *\end{array}$ & $\begin{array}{c}0.820 \\
* *\end{array}$ & -0.055 & - \\
\hline
\end{tabular}

Note. $\mathrm{N}=54$. All correlations are reported at the team level. For simplicity, GD, AD, TD, TS, HD, IE, TI, CO and CR represent team gender diversity, team age diversity, team tenure diversity, team size, team hometown diversity, team information exchange, team identification, team conformity and team creativity respectively. ${ }^{*} p<0.05 .{ }^{* *} p<0.01$.

\subsection{Findings}

Since all the variables in our model were in team level, we adopted the hierarchical regression analyses in this work according to the previous researches $[8,60,63,76]$ and the result was shown in Table 2.

Table 2. Results of regression analysis.

\begin{tabular}{|c|c|c|c|c|c|c|c|c|c|}
\hline \multirow[t]{2}{*}{ Independent Variable } & \multicolumn{4}{|c|}{ Model 1: Team Information Exchange } & \multicolumn{5}{|c|}{ Model 2: Team Creativity } \\
\hline & Step 1 & Step 2 & Step 3 & Step 4 & Step 1 & Step 2 & Step 3 & Step 4 & Step 5 \\
\hline GD & 0.00 & 0.00 & 0.02 & -0.01 & 0.01 & 0.01 & 0.01 & 0.02 & -0.02 \\
\hline $\mathrm{AD}$ & 0.19 & 0.11 & 0.17 & 0.16 & 0.15 & 0.07 & 0.00 & -0.04 & -0.05 \\
\hline TD & 0.20 & 0.09 & 0.05 & 0.05 & 0.22 & 0.11 & 0.05 & 0.08 & 0.05 \\
\hline TS & $-0.10^{* *}$ & -0.03 & 0.00 & 0.01 & $-0.11^{* *}$ & -0.02 & 0.00 & 0.00 & -0.01 \\
\hline \multicolumn{10}{|l|}{ Main effects } \\
\hline $\mathrm{HD}$ & & $-2.04 * *$ & $-1.34^{* *}$ & $-1.82 * *$ & & $-2.61^{* *}$ & $-1.10^{* *}$ & $-1.13^{* *}$ & -1.10 \\
\hline $\begin{array}{l}\text { TI } \\
\text { IE }\end{array}$ & & & $0.35^{* *}$ & $0.37^{* *}$ & & & $0.74^{* *}$ & $0.75^{* *}$ & $0.69^{* *}$ \\
\hline $\mathrm{CO}$ & & & & & & & & -0.16 & -0.16 \\
\hline \multicolumn{10}{|l|}{ Interactions } \\
\hline $\mathrm{HD}^{*} \mathrm{TI}$ & & & & $0.88^{* *}$ & & & & & \\
\hline $\mathrm{IE}^{*} \mathrm{CO}$ & & & & & & & & & $0.49 * *$ \\
\hline R2 & 0.26 & 0.63 & 0.71 & 0.75 & 0.24 & 0.64 & 0.78 & 0.79 & 0.82 \\
\hline Adj-R2 & 0.25 & 0.62 & 0.71 & 0.75 & 0.22 & 0.63 & 0.77 & 0.76 & 0.80 \\
\hline$\Delta \mathrm{R} 2$ & 0.27 & 0.37 & 0.08 & 0.04 & 0.24 & 0.40 & 0.14 & 0.01 & 0.03 \\
\hline $\mathrm{F}$ & $18.68^{* *}$ & $43.56^{* *}$ & $41.57^{* *}$ & $37.00 * *$ & $16.14^{* *}$ & $46.15^{* *}$ & $59.65^{* *}$ & $46.54^{* *}$ & 42.84 ** \\
\hline$\Delta \mathrm{F}$ & 18.68 ** & $50.61 * *$ & $14.51 * *$ & $7.39^{* *}$ & $16.14^{* *}$ & $58.36 * *$ & 31.48 ** & 2.36 & $6.64^{* *}$ \\
\hline
\end{tabular}

Note. $\mathrm{N}=54 . \mathrm{GD}, \mathrm{AD}, \mathrm{TD}, \mathrm{TS}, \mathrm{HD}, \mathrm{IE}, \mathrm{TI}, \mathrm{CO}$ and $\mathrm{CR}$ represent team gender diversity, team age diversity, team tenure diversity, team size, team hometown diversity, team information exchange, team identification, team conformity and team creativity respectively. ${ }^{*} p<0.05 .{ }^{* *} p<0.01$.

To test Hypothesis 1, which posited that team hometown diversity was negatively related to team information exchange, we set team information exchange as the dependent variable and entered control variables in step 1 of Model 1 in Table 2. Team hometown diversity was entered into the model in step 2 . The result proved that team hometown diversity was significantly negative with team information exchange $(\beta=-2.04, p<0.01)$, which demonstrated that the higher of the diversity of the employees' hometowns, the lower level of team information exchange would be.

To test Hypothesis 2 , which assumed that team identification positively moderated the relationship between team hometown diversity and team information exchange, team identification was added into Model 1 as step 3 . The interaction term of team hometown diversity and team information exchange was entered into Model 1 as step 4 . The hypothesis was supported $(\beta=0.88, p<0.01)$, which illustrated 
that team hometown diversity was less negatively related to team information exchange when team identification was higher than when it was low. The moderation effect of team identification on the relationship between team hometown diversity and team information exchange was shown in Figure 2, which was drawn by the previous suggestion [85].

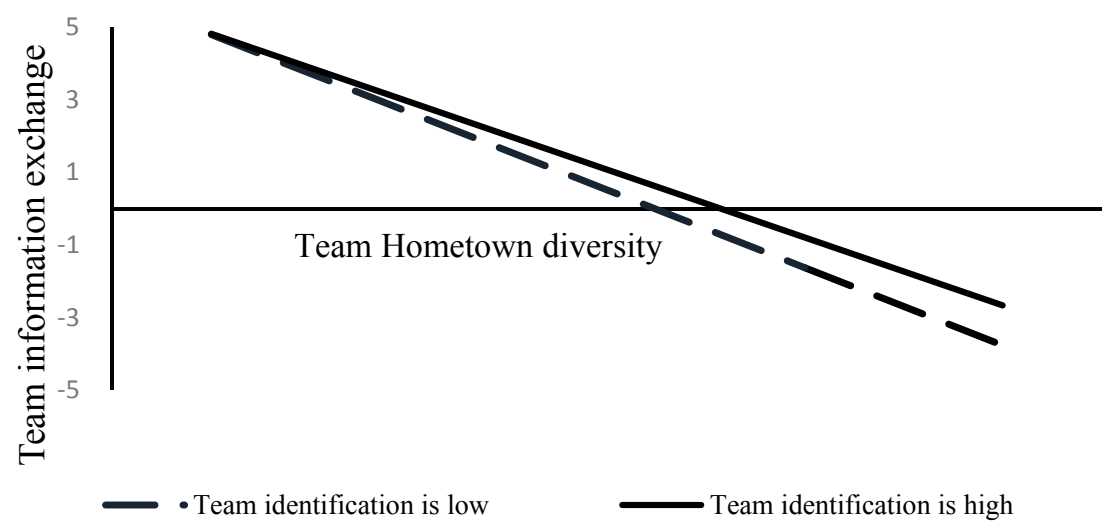

Figure 2. Moderating effect of Team identification.

To test Hypothesis 3, which supposed that team hometown diversity was significantly negative with team creativity, we set team creativity as the dependent variable and entered the control variables as step 1 of Model 2 in Table 2. The team information exchange was entered into the Model 2 as step 2, and the result proved Hypothesis $3(\beta=-2.61, p<0.01)$. The result implied that when team hometown diversity was high, team creativity was low.

To test Hypothesis 4, which posited that team information exchange was positively related to team creativity, team information exchange was added into Model 2 as step 3 . The regression result supported our hypothesis $(\beta=0.74, p<0.01)$, and when team information exchange was at a high level, team creativity was high.

By combining step 2 in Model 1 and steps 2 and 3 in Model 2, the mediation effect of team information between team hometown diversity and team creativity was tested, thus Hypothesis 5 was supported. To test Hypothesis 6, we entered the team conformity and interaction term of team information exchange and team conformity as steps 4 and 5 in Model 2 . The hypothesis was supported ( $\beta=0.49, \mathrm{p}<0.01$ ), which showed that team creativity was more positively related to team creativity when team conformity was low, rather than when it was high. The result was shown in Figure 3. Thus, all hypotheses were supported.

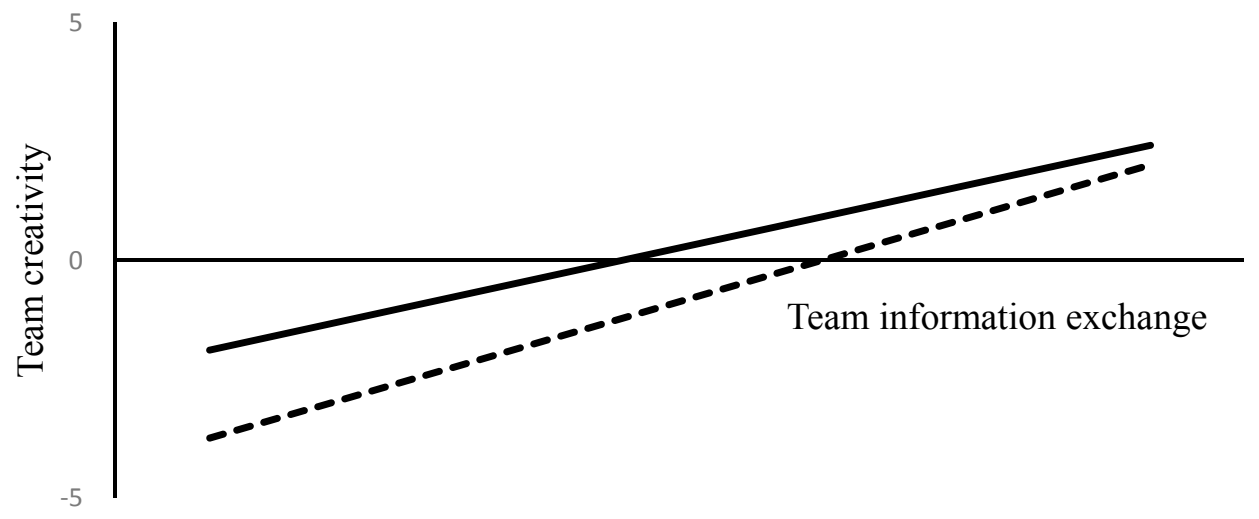

- Team Conformity is low $\quad$ - - Team Conformity is high

Figure 3. Moderating effect of Team Conformity. 


\section{Discussion}

\subsection{Findings}

To our knowledge, this work was among the first to research the relationship between team hometown diversity and team creativity, and the mediation effect of team information exchange between team hometown diversity and team creativity, and the moderation effect of team identification between team hometown diversity and team creativity and the moderation effect of team conformity between team information exchange and team creativity. We found that team hometown diversity was negatively related to both team information exchange and team creativity, while team information exchange was significantly positive with team creativity, and the mediation effect of team information exchange between the relationship of team hometown diversity and team creativity was also verified. The moderation effect of team identification was tested and the relationship between team hometown diversity and team information exchange was less negative when team identification was high than when it was low. Similarly, team conformity moderated the relationship between team information exchange and team creativity, and the relationship was less positive when team conformity was high than when it was low.

\subsection{Theoretical Implications}

This work made at least four contributions. First, this research was among the first to research the impact of team hometown diversity on team creativity, which supplemented the gap and provided a new perspective for exploration of team creativity in the future. Second, a two-wave design was adopted to check the dynamic impact of earlier team information exchange and team identification on team creativity afterwards, which made our model logically reasonable and can be replicated for future studies. Third, by using supervisor and subordinate ratings together and conducting electronic and paper surveys together, the results avoided the common method error and became more persuasive. Fourth, we included a large dataset from a broad range of companies, which maximized the variables and generated our results.

From the perspective of sustainable development, our work also provided implications for the development of companies. Since creativity is the driving force for companies to develop sustainably, this topic has always attracted the research interests of scholars. Extensive literature has mainly set out from the view of technology how creative ideas are generated and what kind of organizational environment and management strategies are helpful for that still need to be explored. This work provided a perspective that team hometown diversity was negatively related to team creativity while team information exchange was positively related to team creativity. In addition, people categorize others with similar attributes into the same group and would like to communicate with them and even build a trusted relationship with them, which is a key antecedent of team creativity. Meanwhile, team identification decreased the negative impact of team hometown diversity on team information exchange, and team conformity decreased the positive effect of team information exchange on team creativity. Therefore, HR managers and company leaders can research how to enhance team identification and develop more proactive company culture based on this work to promote the sustainable development of their companies.

\subsection{Practical Implications}

This work researches the influence of cultural diversity on the organization and the factors contributing to the sustainable development of the company, which is known as team creativity. The practical implications are as follows. First, team hometown diversity is found to be negatively related to team creativity, which is consistent with previous research on demographic diversity and team creativity [19,51,52]. Regarding the team leaders, it is important to know whether team members come from the same hometown and share similar attributes such as dialect. Leaders should try to divide them into the same group when others factors are fixed, which might be good for the generation 
of novel ideas. Additionally, a suitable circumstance and motivation policy of information exchange should be provided as the team members' hometown diversity impacts team creativity through the role of team information exchange. Moreover, since team identification moderates the relationship between team hometown diversity and team creativity in a positive way, leaders should spend more time on building the employees' identification of the company, especially in a hometown-diverse team. Finally, leaders should encourage employees to work in a proactive way and generate novel ideas rather than always thinking inside the box.

\subsection{Limitations and Future Research}

There still existed limitations in this work. Although we adopted a two-wave research design, this work was not a longitude study, which could not entirely demonstrate the dynamic relationship of team hometown diversity, team identification, team information exchange, team conformity and team creativity. In addition, the high correlations among team information exchange, team identification, and team creativity could be caused by the employees' desired effect.

Future research should pay more attention to the relationship between team hometown diversity and team creativity. Additionally, a longitude study should be conducted and the dynamic process of how demographic diversity influences team creativity should be further explained in the future. A cross-level study can also be designed to research how organization-level variables impact on the team creativity or how team-level variables impact on individual creativity.

\section{Conclusions}

This work was among the first to investigate the relationship between team members' hometown diversity and team creativity, which provides a new perspective on team creativity, especially in China. Leaders may improve their team creativity by getting familiar with the diversity of employees and maximizing the team members' identification to the company as well as promoting team information exchange and motivating proactive and divergent thinking.

Specifically, team hometown diversity was negatively related to team creativity, partly through the role of team information exchange. Leaders should be clear about that when the other demographic factors are controlled, the function of team hometown diversity of the team members is obviously important. Based on common attributes, such as dialect and culture, team members are willing to communicate and interact with each other and possibly put forward novel ideas easily when different views collide. Thus, team leaders should create a suitable circumstance for this kind of interaction. Additionally, the higher the identification of team members on their team, the less impact the team hometown diversity would function on the information exchange of team members, which is helpful for team leaders, especially when it is hard to allot demographically similar employees into one team. Consistent with enhancing team identification, encouraging employees to think outside the box is what team leaders can also do to promote team creativity.

Author Contributions: Conceptualization, J.L.; Data curation, J.L. and G.X.; Formal analysis, J.L.; Funding acquisition, M.Z.; Investigation, J.L.; Methodology, J.L.; Resources, M.Z.; Software, J.L. and C.L.; Supervision, M.Z.; Writing—original draft, J.L.; Writing—review \& editing, J.L.

Funding: This work was supported by the Fundamental Research Funds of Central Universities of China and the fund number is 2016B31914.

Acknowledgments: In this section, you can acknowledge any support given which is not covered by the author contribution or funding sections. This may include administrative and technical support, or donations in kind (e.g., materials used for experiments).

Conflicts of Interest: The authors declare no conflicts of interest. 


\section{References}

1. Pil, F.K.; Cohen, S.K. Modularity: Implications for imitation, innovation, and sustained advantage. Acad. Manag. J. 2006, 31, 995-1011. [CrossRef]

2. Kim, W.; Park, J. Examining structural relationships between work engagement, organizational procedural justice, knowledge sharing, and innovative work behavior for sustainable organizations. Sustainability 2017, 9, 205. [CrossRef]

3. Zhou, J.; Shin, S.J.; Brass, D.J.; Choi, J.; Zhang, Z.X. Social networks, personal values, and creativity: Evidence for curvilinear and interaction effects. J. Appl. Psychol. 2009, 94, 1544-1552. [CrossRef] [PubMed]

4. Homan, A.C.; Buengeler, C.; Eckhoff, R.A.; Van Ginkel, W.P.; Voelpel, S.C. The interplay of diversity training and diversity beliefs on team creativity in nationality diverse teams. J. Appl. Psychol. 2015, 100, 1456-1467. [CrossRef] [PubMed]

5. Han, J.; Han, J.; Brass, D. Human capital diversity in the creation of social capital for team creativity. J. Organ. Behav. 2014, 35, 54-71. [CrossRef]

6. Dayan, M.; Di Benedetto, C.A. Team intuition as a continuum construct and new product creativity: The role of environmental turbulence, team experience, and stress. Res. Policy. 2011, 40, 276-286. [CrossRef]

7. Harrison, D.; Klein, K. What's the difference? Diversity constructs as separation, variety, or disparity in organizations. Acad. Manag. Rev. 2007, 32, 1199-1228. [CrossRef]

8. Dayan, M.; Ozer, M.; Almazrouei, H. The role of functional and demographic diversity on new product creativity and the moderating impact of project uncertainty. Ind. Mark. Manag. 2017, 61, 144-154. [CrossRef]

9. Horwitz, S.; Horwitz, I. The effects of team diversity on team outcomes: A meta-analytic review of team demography. J. Manag. 2007, 6, 987-1015. [CrossRef]

10. McLeod, P.L.; Lobel, S.A.; Cox, T.H., Jr. Ethnic diversity and creativity in small groups. Small Group Res. 1996, 27, 248-264. [CrossRef]

11. Bantel, K.A.; Jackson, S.E. Top management and innovations in banking: Does the composition of the top team make a difference? Strateg. Manag. J. 1989, 10, 107-124. [CrossRef]

12. Jackson, S.E.; Joshi, A.; Erhardt, N.L. Recent research on team and organizational diversity: SWOT analysis and implications. J. Manag. 2003, 29, 801-830. [CrossRef]

13. Somech, A.; Drach-Zahavy, A. Translating team creativity to innovation implementation: The role of team composition and climate for innovation. J. Manag. 2013, 39, 684-708. [CrossRef]

14. Amabile, T.M. A model of creativity and innovation in organizations. In Research in Organizational Behavior; Staw, B.M., Cummings, L.L., Eds.; JAI Press: Greenwich, CT, USA, 1988; pp. 123-167.

15. Cox, T.H.; Lobel, S.A.; McLeod, P.L. Effects of ethnic group cultural differences on cooperative and competitive behavior on a group task. Acad. Manag. J. 1991, 34, 827-847. [CrossRef]

16. De Dreu, C.K.W.; West, M.A. Minority dissent and team innovation: The importance of participation in decision making. J. Appl. Psychol. 2001, 86, 1191-1201. [CrossRef] [PubMed]

17. Byrne, D. The Attraction Paradigm; Academic Press: New York, NY, USA, 1971.

18. Chua, R.Y.J. Innovating at cultural crossroads: How multicultural social networks promote idea flow and creativity. J. Manag. 2018, 44, 1119-1146. [CrossRef]

19. Dahlin, K.B.; Weingart, L.R.; Hinds, P.J. Team diversity and information use. Acad. Manag. J. 2005, 48, 1107-1123. [CrossRef]

20. van Knippenberg, D.; De Dreu, C.K.W.; Homan, A.C. Work group diversity and group performance: An integrative model and research agenda. J. Appl. Psychol. 2004, 89, 1008-1022. [CrossRef] [PubMed]

21. Joshi, A.; Roh, H. The role of context in work team diversity research: A meta-analytic review. Acad. Manag. J. 2009, 52, 599-627. [CrossRef]

22. Van der Vegt, G.; Bunderson, J.S. Learning and performance in multidisciplinary teams: The importance of collective team identification. Acad. Manag. J. 2005, 48, 532-547. [CrossRef]

23. Fiske, S.T.; Neuberg, S.L. A continuum of impression formation, from category-based to individuating processes: Influences of information and motivation on attention and interpretation. Adv. Exp. Soc. Psychol. 1990, 23, 1-74.

24. Messick, D.; Mackie, D. Intergroup relations. Annu. Rev. Psychol. 1989, 40, 45-81. [CrossRef] [PubMed]

25. Stangor, C.; Lynch, L.; Duan, C.; Glas, B. Categorization of individuals on the basis of multiple social features. J. Pers. Soc. Psychol. 1992, 62, 207-218. [CrossRef] 
26. Hewstone, M.; Hantzi, A.; Johnston, L. Social categorization and person memory: The pervasiveness of race as an organizing principle. Eur. J. Soc. Psychol. 1991, 21, 517-528. [CrossRef]

27. Harrison, D.A.; Price, K.H.; Gavin, J.H.; Florey, A.T. Time, teams, and task performance: Changing effects of surface- and deep-level diversity on group functioning. Acad. Manag. J. 2002, 45, 1029-1045. [CrossRef]

28. Chan, K.W.; Wu, J.J. The mediating role of communication satisfaction in relational demography-A study in Macao, SAR context. Asia Pac. Bus. Rev. 2009, 15, 547-564. [CrossRef]

29. Tajfel, H.; Turner, J.C. The social identity theory of intergroup behavior. In Psychology of Intergroup Relations; Worchel, S., Austin, W.G., Eds.; Nelson-Hall: Chicago, IL, USA, 1986; pp. 7-24.

30. Farh, J.; Tsui, A.S.; Xin, K.; Cheng, B. The influence of relational demography and Guanxi: The Chinese case. Organ Sci. 1998, 9, 471-488. [CrossRef]

31. Blau, P.M. Interaction: Social exchange. Int. Encycl. Soc. Sci. 1968, 7, 452-458.

32. Hwang, K.K. Face and favor: The Chinese power game. Am. J. Sociol. 1987, 92, 944-974. [CrossRef]

33. Gino, F.; Argote, L.; Miron-Spektor, E.; Todorova, G. First, get your feet wet: The effect of learning from direct and indirect experience on team creativity. Organ. Behav. Hum. Decis. Process. 2010, 111, 102-115. [CrossRef]

34. Keller, R.T. Cross-functional project groups in research and new product development: Diversity, communications, job stress, and outcomes. Acad. Manag. J. 2001, 44, 547-555. [CrossRef]

35. Hoever, I.J.; van Knippenberg, D.; van Ginkel, W.P.; Barkema, H.G. Fostering team creativity: Perspective taking as key to unlocking diversity's potential. J. Appl. Psychol. 2012, 97, 982-996. [CrossRef] [PubMed]

36. McGrath, J.E.; Berdahl, J.L.; Arrow, H. Traits, expectations, culture, and clout: The dynamics of diversity in work groups. In Diversity in Work Teams: Research Paradigms for a Changing Workplace; Jackson, S.E., Ruderman, M.N., Eds.; American Psychological Association: Washington, DC, USA, 1995; pp. 17-45.

37. Tajfel, H. Social Identity and Intergroup Relations; Cambridge University Press: Cambridge, UK, 1982.

38. Turner, J.C. Rediscovering the Social Group: A Self-Categorization Theory; Blackwell: Oxford, UK, 1987.

39. Tsui, A.; Farh, J. Where guanxi matters-Relational demography and Guanxi in the Chinese context. Work Occup. 1997, 24, 56-79. [CrossRef]

40. Brewer, M.B.; Miller, N. Beyond the contact hypothesis: Theoretical perspectives on desegregation. In Groups in Contact; Miller, N., Brewer, M.B., Eds.; Academic Press: San Diego, CA, USA, 1984.

41. Nahapiet, J.; Ghoshal, S. Social capital, intellectual capital, and the organizational advantage. Acad. Manag. Rev. 1998, 23, 242-266. [CrossRef]

42. Collins, C.J.; Smith, K.G. Knowledge exchange and combination: The role of human resource practices in the performance of high-technology firms. Acad. Manag. J. 2006, 49, 544-560. [CrossRef]

43. Mael, F.; Ashforth, B.E. Alumni and their alma mater: A partial test of the reformulated model of organizational identification. J. Organ. Behav. 1992, 13, 103-123. [CrossRef]

44. Emerson, R.M. Social exchange theory. Annu. Rev. Sociol. 1976, 2, 335-362. [CrossRef]

45. Stafford, L. Social exchange theories. In Engaging Theories in Interpersonal Communication: Multiple Perspectives; Baxter, L.A., Braithwaite, D.O., Eds.; Sage: Thousand Oaks, CA, USA, 2008; pp. 377-389.

46. Meyer, J.P.; Becker, T.E.; Van Dick, R. Social identities and commitments at work: Toward an integrative model. J. Organ. Behav. 2006, 27, 665-683. [CrossRef]

47. Huang, Q.; Davison Rand, G.U.J. Impact of personal and cultural factors on knowledge sharing in China. Asia Pac. J. Manag. 2008, 25, 451-471. [CrossRef]

48. Ely, R.J.; Thomas, D.A. Cultural diversity at work: The effects of diversity perspectives on work group processes and outcomes. Adm. Sci. Q. 2001, 46, 229-273. [CrossRef]

49. van Knippenberg, D.; van Schie, E.C.M. Foci and correlates of organizational identification. J. Occup. Organ. Psychol. 2000, 73, 137-147. [CrossRef]

50. Van Knippenberg, D.; van Knippenberg, B.; De Cremer, D.; Hogg, M.A. Leadership, self, and identity: A review and research agenda. Leadersh. Q. 2004, 15, 825-856. [CrossRef]

51. Nederveen Pieterse, A.N.; van Knippenberg, D.; van Dierendonck, D. Cultural diversity and team performance: The role of team member goal orientation. Acad. Manag. J. 2013, 56, 782-804. [CrossRef]

52. Stahl, G.K.; Maznevski, M.L.; Voigt, A.; Jonsen, K. Unraveling the effects of cultural diversity in teams: A meta-analysis of research on multicultural work groups. J. Int. Bus. Stud. 2010, 41, 690-709. [CrossRef]

53. Jackson, S.E.; Brett, J.F.; Sessa, V.I.; Cooper, D.M.; Julin, J.A.; Peyronnin, K. Some differences make a difference: Individual dissimilarity and group heterogeneity as correlates of recruitment, promotions and turnover. J. Appl. Psychol. 1991, 76, 675-689. [CrossRef] 
54. Hobman, E.; Bordia, P.; Gallois, C. Perceived dissimilarity and work group involvement-The moderating effects of group openness to diversity. Group Organ. Manag. 2004, 29, 560-587. [CrossRef]

55. Burt, R.S. Structural holes and good ideas. Am. J. Sociol. 2004, 110, 349-399. [CrossRef]

56. Obstfeld, D. Social networks, the tertius iungens orientation, and involvement in innovation. Adm. Sci. Q. 2005, 50, 100-130. [CrossRef]

57. Edmondson, A. Psychological safety and learning behavior in work teams. Adm. Sci. Q. 1999, 44, $350-383$. [CrossRef]

58. Gong, Y.; Cheung, S.Y.; Wang, M.; Huang, J.C. Unfolding the proactive process for creativity: Integration of the employee proactivity, information exchange, and psychological safety perspectives. J. Manag. 2012, 38, 1611-1633. [CrossRef]

59. Cohen, W.M.; Levinthal, D.A. Absorptive capacity: A new perspective in learning and innovation. Adm. Sci. Q. 1990, 17, 178-184. [CrossRef]

60. Perry-Smith, J.E. Social yet creative: The role of social relationships in facilitating individual creativity. Acad. Manag. J. 2006, 49, 85-101. [CrossRef]

61. Johnson, M.D.; Hollenbeck, J.R.; Humphrey, S.E.; Ilgen, D.R.; Jundt, D.; Meyer, C.J. Cutthroat cooperation: Asymmetrical adaptation of team reward structures. Acad. Manag. J. 2006, 49, 103-119. [CrossRef]

62. Amabile, T.M.; Khaire, M. Creativity and the role of the leader. Harv. Bus. Rev. 2008, 86, 100-109. [PubMed]

63. Chiang, Y.; Hsu, C.; Shih, H. Experienced high performance work system, extroversion personality, and creativity performance. Asia Pac. J. Manag. 2015, 32, 531-549. [CrossRef]

64. Shin, S.J.; Zhou, J. When is educational specialization heterogeneity related to creativity in research and development teams? Transformational leadership as a moderator. J. Appl. Psychol. 2007, 92, 1709-1721. [CrossRef] [PubMed]

65. Schwartz, S. Are there universal aspects in the structure and contents of human-values? J. Soc. Issues 1994, 50, 19-45. [CrossRef]

66. Schwartz, S.J. Universals in the content and structure of values: Theory and empirical tests in 20 countries. In Advances in Experimental Social Psychology; Zanna, M., Ed.; Academic Press: New York, NY, USA, 1992.

67. Kirton, M. Adaptors and innovators: A description and measure. J. Appl. Psychol. 1976, 61, $622-629$. [CrossRef]

68. Schaubroeck, J.; Lam, S.S.K.; Cha, S.E. Embracing transformational leadership: Team values and the impact of leader behavior on team performance. J. Appl. Psychol. 2007, 92, 1020-1030. [CrossRef] [PubMed]

69. Chen, N.Y.; Tjosvold, D.; Huang, X.; Xu, D. Newcomer socialization in China: Effects of team values and goal interdependence. Int. J. Hum. Resour. Manag. 2011, 22, 3317-3337. [CrossRef]

70. Pech, R.J. Termites, group behavior and the loss of innovation: Conformity rules! J. Manag. Psychol. 2001, 16, 559-574. [CrossRef]

71. Madjar, N.; Greenberg, E.; Chen, Z. Factors for radical creativity, incremental creativity, and routine, noncreative performance. J. Appl. Psychol. 2011, 96, 730-743. [CrossRef] [PubMed]

72. Levitt, T. Creativity is not enough. Harv. Bus. Rev. 2002, 8, 137-144.

73. Brislin, R.W. Translation and content analysis of oral and written materials. In Handbook of Cross-Cultural Psychology; Triandis, H.C., Lambert, W.W., Eds.; Allyn \& Bacon: Boston, MA, USA, 1980; pp. 349-444.

74. Podsakoff, P.M.; MacKenzie, S.B.; Lee, J.Y.; Podsakoff, N.P. Common method biases in behavioral research: A critical review of the literature and recommended remedies. J. Appl. Psychol. 2003, 88, 879-903. [CrossRef] [PubMed]

75. Blau, P.M. Inequality and Heterogeneity; Free Press: New York, NY, USA, 1977.

76. Subramaniam, M.; Youndt, M.A. The influence of intellectual capital on the types of innovative capabilities. Acad. Manag. J. 2005, 48, 450-463. [CrossRef]

77. Tang, C.; Shang, J.; Naumann, S.E.; von Zedtwitz, M. How team identification and expertise identification Affect R\&D Employees' creativity. Creat. Innov. Manag. 2014, 23, 276-289. [CrossRef]

78. Lin, B.; Law, K.S.; Zhou, J. Why is underemployment related to creativity and OCB? A task-crafting explanation of the curvilinear moderated relations. Acad. Manag. J. 2017, 60, 156-177. [CrossRef]

79. Amabile, T.M. Creativity in Context: Update to The Social Psychology of Creativity; Westview Press: Boulder, CO, USA, 1996.

80. Gong, Y.; Kim, T.; Lee, D.; Zhu, J. A multilevel model of team goal orientation, information exchange, and creativity. Acad. Manag. J. 2013, 56, 827-851. [CrossRef] 
81. Miron, E.; Erez, M.; Naveh, E. Do personal characteristics and cultural values that promote innovation, quality, and efficiency compete or complement each other? J. Organ. Behav. 2004, 25, 175-199. [CrossRef]

82. Kilduff, M.; Angelmar, R.; Mehra, A. Top management-team diversity and firm performance: Examining the role of cognitions. Organ Sci. 2000, 11, 21-34. [CrossRef]

83. Horwitz, S. The compositional impact of team diversity on performance: Theoretical considerations. Hum. Resour. Dev. Rev. 2005, 4, 219-245. [CrossRef]

84. IBM SPSS Statistics for Windows, version 21.0; IBM Corp: Armonk, NY, USA, 2012.

85. Aiken, L.S.; West, S.G. Multiple Regression: Testing and Interpreting Interactions; Sage: Thousand Oaks, CA, USA, 1991. 